\title{
Eumycetoma by Madurella mycetomatis with 30 years of evolution: therapeutic challenge ${ }^{*}$ \\ Eumicetoma por Madurella mycetomatis com 30 anos de evolução: desafio terapêutico
}

\author{
Felipe Maurício Soeiro Sampaio ${ }^{1}$ \\ Leonardo Pereira Quintella ${ }^{3}$ \\ Janice Mary Chicarino de Oliveira Coelho ${ }^{5}$
}

\author{
Maria Clara Gutierrez Galhardo² \\ Paulo Roberto Cotrim de Souza ${ }^{4}$ \\ Antonio Carlos Francesconi do Valle ${ }^{2}$
}

\begin{abstract}
We report a case of eumycetoma by Madurella mycetomatis on the buttocks and thighs in an adult immunocompetent patient, diagnosed after 30 years of clinical development. He was treated over four years with fluconazol and itraconazol associated with five times surgical excisions of subcutaneous nodules. At the eighth year of follow-up, one nodule recurred on the right infragluteal region, which was excised surgically and has remained asymptomatic ever since.
\end{abstract}

Keywords: Fluconazole; Itraconazole; Mycetoma

Resumo: Relatamos o caso de um paciente adulto, imunocompetente, com eumicetoma por Madurella mycetomatis, localizado nos glúteos e coxas, diagnosticado após 30 anos de evolução clínica. Tratado no decorrer de quatro anos com fluconazol e itraconazol, associado a cinco tempos cirúrgicos de exérese dos nódulos subcutâneos. No oitavo ano de follow-up ocorreu recidiva de apenas um nódulo na região infraglútea, o qual foi excisado cirurgicamente, mantendo-se assintomático desde então.

Palavras-chave: Fluconazol; Itraconazol; Micetoma

\section{INTRODUCTION}

Mycetoma is a chronic subcutaneous infection, caused by the traumatic inoculation of ground saprophytes fungi (eumycetoma) and filamentous bacteria (actinomycetoma) ${ }^{1-9}$ It predominates in tropical and subtropical regions, mainly in rural areas, affecting individuals with a habit of walking and working without protection. ${ }^{1,3}$ The most frequent clinical characteristics are increase in volume of the affected area, nodules, fistulas and exudation with or without grains. In more than $70 \%$ of cases it is situated in the feet, hands, arms, legs and back. ${ }^{1,4}$ By local invasion it reaches the fascia, muscles, articulations and bones. ${ }^{3,4,5}$ Systemic signs and symptoms are uncommon and when present are the result of the involvement of adjacent organs such as the lungs and the brain. ${ }^{7}$ Although causative agents vary according to

Received on 17.09.2012.

Approved by the Advisory Board and accepted for publication on 13.11.2012

* Work performed at the Dermatology Laboratory, Evandro Chagas Clinical Research Institute, Oswaldo Cruz Foundation (IPEC-FIOCRUZ) - Rio de Janeiro, Brazil

Conflict of interest: None

Financial funding: None

MD, Tropical Dermatology Service at the Army Central Hospital (HCE) - Rio de Janeiro (RJ), Brazil.

MD, PhD, Laboratory of Dermatology in Infectious Diseases at the Evandro Chagas Research Institute, Oswaldo Cruz Foundation (IPEC-FIOCRUZ) - Rio de Janeiro (RJ), Brazil

MD, PhD, Department of Anatomic Pathology. Evandro Chagas Clinical Research Institute, Oswaldo Cruz Foundation (IPEC-FIOCRUZ) - Rio de Janeiro (RJ), Brazil.

MD, chief of the Dermatology Service at the Federal Hospital of Bonsucesso (HFB) - Rio de Janeiro, Brazil.

MD, Department of Anatomic Pathology. Evandro Chagas Clinical Research Institute, Oswaldo Cruz Foundation (IPEC-FIOCRUZ) - Rio de Janeiro, Brazil. 
geographical location, actinomycetomas predominate worldwide. ${ }^{1,6}$ In eumycetoma cases, Madurella mycetomatis is one of the main agents..$^{1-9}$ In Brazil, where it is a neglected disease without compulsory notification, the incidence and prevalence of mycetomas are unknown. Retrospective studies by Castro and Piquero-Casals described a ratio of 3:1 between actinomycetoma and eumycetoma, with the majority of cases recorded in the North-east region. ${ }^{6}$

\section{CASE REPORT}

We describe a case of a white 49-year-old male patient, from the state of Ceará, Brazil, who presented asymptomatic cutaneous lesions, in the thighs and gluteus, for 30 years, with progressive swelling of the affected areas. The patient reported the onset of the lesion after a local trauma, caused by sliding down a waterfall of his home state.

Physical examination revealed multiple erythematous nodules, both palpable and visible, associated with fistulas with exudation of serosanguineous material and black grains, located on the anterior, lateral and posterior face of the proximal third of the thigh and in the infragluteal regions (Figure 1). Edema and local erythema were present, with no palpable lymphadenopathy. The patient was in good general condition, with no systemic signs or symptoms.

The histopathological study of one of the lesions, with hematoxylin-eosin and Grocott's methenamine silver stains, showed amorphous brownish grain-like material with eosinophilic edges and septal hyphae at its core (Figure 2). The culture of the grain, in Sabouraud Agar, grew Madurella mycetomatis. Radiological evaluation by computed tomography showed a considerable amount of nodular thickening at the skin and subcutaneous levels, with unaffected muscle and bone.

The patient was treated with fluconazole $200 \mathrm{mg} /$ day and itraconazole $200 \mathrm{mg} /$ day for four years, undergoing five semiannual surgical procedures aimed at excision of the subcutaneous nodules. Medical discharge was achieved two months after the last surgery, with no clinical or radiological evidence of residual lesions.

Eighth year of follow-up, a new asymptomatic, well delimited skin-colored nodule, of approximately $2 \mathrm{~cm}$ in seize, without a fis- tula was observed in the right infragluteal region (Figure 3). After excisional biopsy of the lesion, with observation of black grains and Madurella mycetomatis growth in culture, the diagnosis of eumycetoma was confirmed (Figure 4). After new image tests showed no remaining lesions, the patient was kept under follow-up, without antifungal chemotherapy.

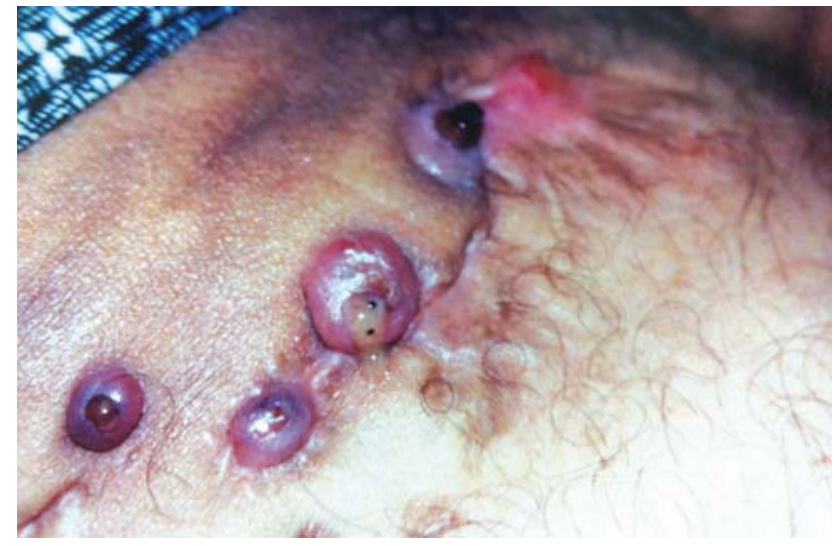

FIGURE 1: Eumycetoma. Nodules and fistules, with exudation and elimination of the grain in the anterior thigh

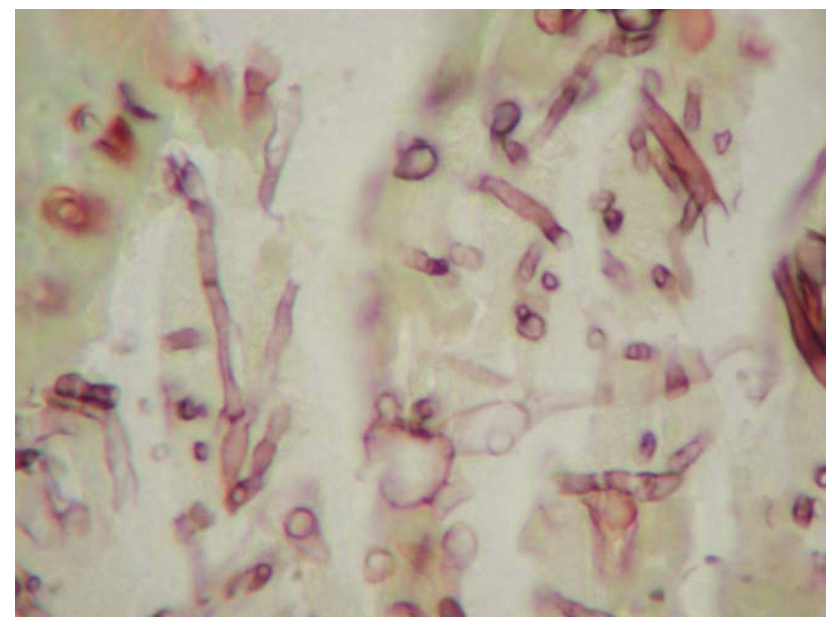

FIGURE 2: Histopathology: Grocott (x400) - Slender, septate and branching hyphaes

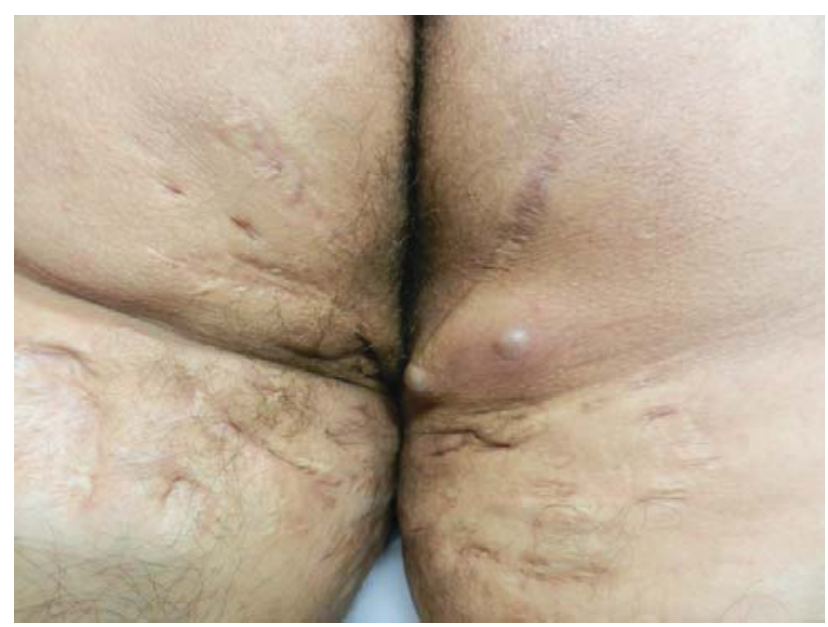

FIGURE 3: Recurrence in the right buttock. Presence of scars on the buttocks and thighs after surgeries for grains excision 


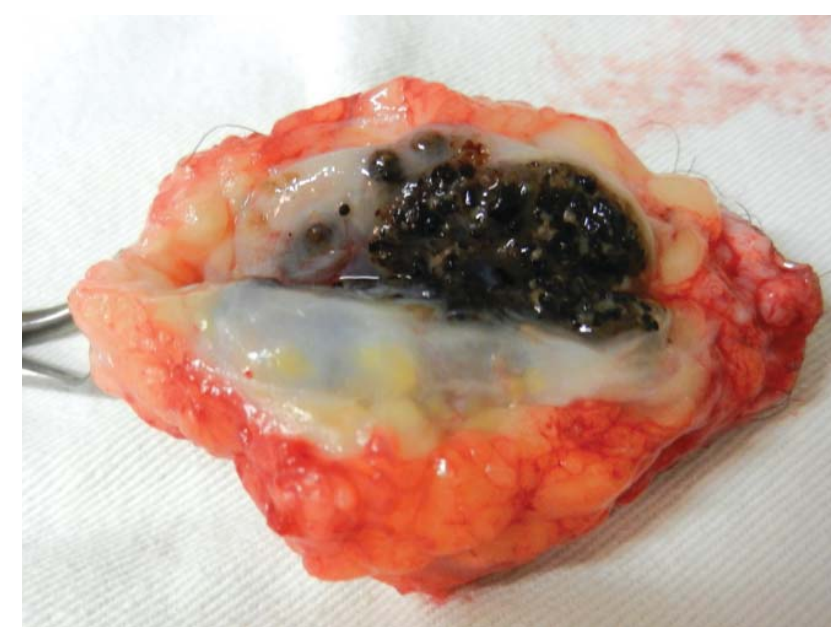

FIGURE 4: Recurrent lesion after excision with black grains inside

\section{DISCUSSION}

Treatment of eumycetomas with systemic antifungals remains challenging and prolonged. In daily practice, itraconazole (200-400mg/day) and ketoconazole $(400 \mathrm{mg} /$ day) are the main antifungals used in the treatment of eumycetomas, with average duration of between 12 and 24 months. In in vitro tests of antifungal sensitivity, Madurella sp. showed susceptibility to voriconazole and posaconazole, which are, however, still not easily available in the public health service. ${ }^{2,3}$ Terbinafine may be used, although the minimum inhibitory concentration (MIC) is above $1.7 \mu \mathrm{g} / \mathrm{ml}$ in in vitro sensitivity tests to Madurella $s p .{ }^{2}$ Intravenous or intralesional Amphotericin B (total of $2-4 \mathrm{~g}$ ) is reserved for disseminated cases or those which do not respond to initial treatment. Corticosteroids with antifungics may be used to reduce the inflammatory process. ${ }^{1}$ In the case described, itraconazole and fluconazole were chosen owing to therapeutic success with other subcutaneous mycoses. ${ }^{8-9}$ Currently, the best treatment for mycetoma is the use of antifungals along with surgery. Antifungals must be applied before and after excision of the lesions, as they promote a regression of the infectious process and of the edema, partial or total closing of the fistulas and healing up of the lesions., ${ }^{2,5}$ Surgery is recommended in localized cases, with the aim of complete removal of the lesions and reduction of the local fibrosis, which makes penetration and action of chemotherapy in the lesions difficult. As reported in this case, often several surgical stages are necessary until the infection is successfully eliminated. During surgery, the subcutaneous nodules must be removed intact, to avoid the spreading of the grains to the adjacent tissue. When the bone is involved, bone curettage may be recommended or even total amputation of the infected limb., ${ }^{4,5}$ Surgical wounds may be left open to heal by secondary intention or closed up primarily. Cure criteria takes into consideration the disappearance of the lesions in clinical and image testing, and there is no consensus as to how long patients must be kept under follow-up. ${ }^{5}$ In eumycetomas, the difficulty of treatment, the importance of surgical complementation and the possibility of relapse should be noted.

\section{REFERENCES}

1. do Valle ACF, Welsh 0, Vera-Cabrera L. Mycetoma. In: Tyring SK, Lupi 0, Hengge UR, editors. Tropical Dermatology. Philadelphia: Elsevier; 2006. p.197-200.

2. van Belkum A, Fahal AH, van de Sande WW. In vitro susceptibility of Madurella mycetomatis to posaconazole and terbinafine. Antimicrob Agents Chemother. 2011;55:1771-3.

3. Loulergue P, Hot A, Dannaoui E, Dallot A, Poirée S, Dupont B, et al. Successful treatment of black-grain mycetoma with voriconazole. Am J Trop Med Hyg. 2006;75:1106-7.

4. El Muttardi N, Kulendren D, Jemec B. Madura foot - mind the soil. J Plast Reconstr Aesthet Surg. 2010;63:e576-8.

5. Venkatswami S, Sankarasubramanian A, Subramanyam S. The Madura foot: looking deep. Int J Low Extrem Wounds. 2012;11:31-42.

6. Castro LG, Piquero-Casals J. Clinical and mycologic findings and therapeutic outcome of 27 mycetoma patients from São Paulo, Brazil. Int J Dermatol. 2008;47:160-3.

7. Maheshwari S, Figueiredo A, Narurkar S, Goel A. Madurella mycetoma--a rare case with cranial extension. World Neurosurg. 2010;73:69-71.

8. Mouchalouat Mde F, Gutierrez Galhardo MC, Zancopé-Oliveira RM, Monteiro Fialho PC, de Oliveira Coelho JM, Silva Tavares PM, et al. Chromoblastomycosis: a clinical and molecular study of 18 cases in Rio de Janeiro, Brazil. Int J Dermatol. 2011;50:981-6

9. Valle AC, Wanke B, Lazéra MS, Monteiro PC, Viegas ML. Entomophthora mycosis by Conidiobolus coronatus. Report of a case successfully treated with the combination of itraconazole and fluconazole. Rev Inst Med Trop Sao Paulo. 2001;43:233-6.

\author{
MAILING ADDRESS: \\ Felipe Maurício Soeiro Sampaio \\ Av. Brasil, 4365 - Manguinhos \\ 21045-900 - Rio de Janeiro - RJ \\ Brazil \\ E-mail:felipemauricio@uol.com.br
}

How to cite this article: Sampaio FMS, Galhardo MCG, Quintella LP, de Souza PRC, Coelho JMCO, Valle ACF. Eumycetoma by Madurella mycetomatis with 30 years of evolution: therapeutic challenge. An Bras Dermatol. 2013;88(6 Suppl 1):S82-4. 